\title{
Atlantic Forest Hotspot: Why We Should Consider Mature Forests a Conservation Priority in the São Paulo Metropolitan Region, Southeastern Brazil
}

\author{
Eduardo Hortal Pereira Barretto ${ }^{1}$, Eduardo Luís Martins Catharino ${ }^{2 *}$ \\ ${ }^{1}$ São Paulo City Herbarium, São Paulo, SP, Brazil \\ ${ }^{2}$ São Paulo Botanical Institute, São Paulo, SP, Brazil \\ Email: ehpbarretto@gmail.com.br, ^mcatarin@uol.com.br
}

How to cite this paper: Barretto, E.H.P. and Catharino, E.L.M. (2022) Atlantic Forest Hotspot: Why We Should Consider Mature Forests a Conservation Priority in the São Paulo Metropolitan Region, Southeastern Brazil. Journal of Environmental Protection, 13, 69-83.

https://doi.org/10.4236/jep.2022.131004

Received: November 17, 2021

Accepted: January 14, 2022

Published: January 17, 2022

Copyright $\odot 2022$ by author(s) and Scientific Research Publishing Inc. This work is licensed under the Creative Commons Attribution International License (CC BY 4.0).

http://creativecommons.org/licenses/by/4.0/

(c) (i) Open Access

\begin{abstract}
The Atlantic Forest is among the 35 hotspots on the planet, and yet few floristic or structural studies have been conducted on mature forest fragments of that biome in Brazil. In view of this knowledge gap and of the need to further comprehend the importance of conserving mature forests, we surveyed the arboreal component of three little-altered forest remnants from the São Paulo metropolitan region (SPMR), southeastern Brazil, and compared our data with the one from other phytosociological studies performed in the region. Mature forests showed a different floristic composition from one of young forests. Overall, the former has a higher number and percentage of threatened and endemic species than the latter, and also a higher exclusivity of occurrence of threatened species. In areas up to twice as smaller, mature forests have 1.5 to 4.3 times more endemic species to the Atlantic Forest and up to 9 times more species threatened with extinction than young forests. These facts, along with the scarcity of remnants of mature forests, led us to consider such forests as hotspots within the Atlantic Forest hotspot in the SPMR, as well as to categorize them as of high relevance for conservation.
\end{abstract}

\section{Keywords}

Threatened Species, Endemic Species, Primary Forest, Tropical Forest, Forest Succession, Biodiversity, Phytosociology

\section{Introduction}

The Atlantic Forest, the biome with the highest plant diversity in Brazil [1] [2], is 
one of the 35 hotspots on the planet [3]. The hotspot concept has been created almost three decades ago, being applied to areas that concentrate an exceptional number of endemic species and that have lost at least $70 \%$ of their primary vegetation [3] [4]. According to [3], the protection of hotspots may constitute an effective way to preserve a large number of species, at low costs.

Currently, identifying areas with high biodiversity is crucial for the conservation of natural environments [5]. In that sense, surveys have increasingly been conducted in hotspots. Recent studies have shown that diversity and/or endemism may vary significantly among localities within the same hotspot [5] [6] [7]. Since the scarcity of financial resources might impair the protection of hotspots in their entirety, preserving small cores with maximum diversity and/or endemism within hotspots might well represent an effective strategy for conservation [5] [6] [8].

According to the survey of existing Atlantic Forest remnants [9], ca. $12.5 \%$ of the original forest cover is estimated to remain, including both primary and secondary vegetation, of which a small portion of unknown dimensions is formed by mature forests. Besides their rarity, the importance of mature or primary tropical forests has been discussed in recent studies. Such importance lies in their high number of exclusive species of trees, lianas and several animal groups [10] as well as in their large number of rare and threatened species [11]. The unique biodiversity of these forests was deemed irreplaceable by [12].

In the Brazilian Atlantic Forest, several studies have approached the arboreal composition, dynamic and structure of forests at different stages of regeneration, but few of those studies were conducted on mature forests [11] [13]. Particularly in São Paulo state, some research on the flora of primary remnants was conducted in the 1970s and 1980s. More recently, there has been a great increase in the number of research on secondary or degraded forests, which represents almost the entirety of floristic studies that are currently being conducted in the state, and thus little attention has been paid to mature forests.

The São Paulo metropolitan region (SPMR) is completely contained within the Green Belt Biosphere Reserve of São Paulo city [14]. It is the largest urban conglomerate of South America, being essentially composed of altered and degraded Atlantic Forest remnants resulting from the intense process of human occupation in the region [15]. Nevertheless, some relatively little altered forest patches, albeit rare and little known, remain in regions like the Morro Grande Forest Reserve [11] [13] [16] [17] and the Cantareira State Park [18] [19].

We aimed to contribute to the characterization of the arboreal structure of mature Atlantic Forest remnants and evaluate the importance of conserving such remnants in the SPMR.

\section{Methods}

\section{Selection and characterization of the study areas:}

To locate mature forests in the SPMR, first we selected 50 fragments by ana- 
lyzing aerial photographs and satellite images, and by consulting with specialists. Then, we visited all fragments and evaluated them following general parameters available in the literature for tropical mature forests [20] [21] [22] [23] [24], such as: large size (in height and diameter); high diversity of tree species; high abundance and diversity of epiphytes and lianas; high species-richness in the understory; and a history of low anthropic interference in the area. From that initial evaluation, we chose three study areas in the SPMR: southernmost São Paulo municipality, Marsilac neighborhood, and inner Capivari-Monos Environmental Protection Area $\left(23^{\circ} \mathrm{S}, 46^{\circ} \mathrm{W}\right)$; western Cotia municipality, in the Morro Grande Forest Reserve $\left(23^{\circ} \mathrm{S}, 47^{\circ} \mathrm{W}\right)$; and private properties in western Itapevi municipality $\left(23^{\circ} \mathrm{S}, 47^{\circ} \mathrm{W}\right)$. The areas are located in fragments of 830 ha (Itapevi), 10,650 ha (Morro Grande), and 12,550 ha (Marsilac), according to information obtained from the mapping of Atlantic Forest remnants in Brazil [9]. All plots are located in the Planalto Atlântico Paulista ('São Paulo State Atlantic Plateau'; 750 - $975 \mathrm{~m}$ altitude). Climate in the region is predominantly temperate wet-type $\mathrm{Cfb}$ [25], and vegetation is represented by the Montane Ombrophilous Dense Forest, of the Atlantic Forest biome [26]. Such forest physiognomy is formed essentially by hygrophytic species and occurs at altitudes of 500 to $1500 \mathrm{~m}$. Regarding their historical background, the study areas are either relatively little disturbed primary forest remnants, possibly explored for the selective harvesting of cabinet-grade hardwoods and the occasional extraction of juçara hearts of palm (Euterpe edulis); or ancient, well-developed secondary forests (while the precise age of remnants is unknown, presumably none of them is below 100 years old).

\section{Sampling}

In each of the three selected areas, we established two $20 \times 50 \mathrm{~m}$ plots, which were subdivided in $10 \times 10 \mathrm{~m}$ plots, totalizing $6000 \mathrm{~m}^{2}$ of sampling area. We measured all tree individuals (including tree ferns, palm trees, and dead individuals) with perimeter at breast height $(\mathrm{PBH}) \geq 15.0 \mathrm{~cm}$. We collected samples from all tree individuals in the plots, from fertile individuals whenever possible.

\section{Data Analysis}

Family-level classification was made following the taxonomic system Angiosperm Phylogeny Group-APG III [27], while species nomenclature followed the List of Species of the Brazilian Flora [28].

To evaluate the importance of conserving mature forests, we compared floristic data, the number of species threatened with extinction, and the number of species endemic to the Brazilian Atlantic Forest, among the phytosociological studies previously performed in the SPMR on forests at different degrees of maturity. In order to avoid distortions, in all comparative analyses we considered only studies that used the plotting method, similar sampling criteria (perimeter at breast height $\geq 15.0 \mathrm{~cm}$ or circumference at breast height $\geq 5.0 \mathrm{~cm}$ ), and sam- 
pling area of up to 0.4 ha (which corresponds to twice the area of each sampled site).

For the floristic analysis we performed a Paired-Group Cluster Analysis using Jaccard's coefficient, and a Detrended Correspondence Analysis-DCA [29], using software Past 2.17c [30]. For that, we elaborated a spreadsheet of presence and absence of species from phytosociological studies performed on forests from the SPMR. Species were synonymized following the List of Species of the Brazilian Flora [28]. Species that either were identified only to the genus or family levels or had no reported occurrence to São Paulo state according to [31] were excluded from the analyses. A priori, we considered mature forests to be those which were classified as such by the authors [32], as well as the areas M, Q, and I of the present study, and young or degraded forests to be the remaining ones in the SPMR [32] [33] [34] [35].

Regarding endemism and conservation status, we compared the number and percentage of species threatened with extinction and of species endemic to the Brazilian Atlantic Forest, among the phytosociological studies previously performed in the SPMR. Classification regarding conservation status was made based on lists of threatened species [36] [37] [38] [39]. Endemism of species from the Brazilian Atlantic Forest was checked on [28].

\section{Results}

\section{Floristic and structural composition}

We sampled 987 tree individuals, 44 of which were dead, distributed over 50 families, 109 genera, 183 native species and one exotic species, Citrus sp. (sampling sufficiency is presented in [11]). Structural parameters of the studied communities, as well as the species richness and IV of families and species, are presented in the Supporting Information.

Myrtaceae and Lauraceae showed the highest richness values (especially at Marsilac and Morro Grande) as well as the highest IV (Figure 1). Lauraceae showed high values of relative dominance, due to the presence of large trees of several species (Beilschmiedia emarginata, Cryptocarya spp., Ocotea catharinensis, $O$. elegans, and $O$. venulosa, among others) and to their high relative frequency, with several transient young individuals being recorded. Myrtaceae not only was the most species-rich family but also showed the highest relative density, being dominant particularly in the understory of the studied forests. The IV was also high for Sapotaceae at Marsilac and Morro Grande (due to the presence of large trees of Micropholis crassipedicellata and Pouteria bullata); Rubiaceae at Itapevi and Morro Grande; and Olacaceae at Itapevi, only (due to the dominance of Heisteria silvianii).

Floristic similarity among forests from the São Paulo metropolitan region

The compilation of 9 floristic surveys resulted in the record of 352 tree species (including tree ferns and palm trees), of which 98 (27.8\%) occurred in both mature and young forests. Mature forests altogether ( 0.8 ha) had 196 species 


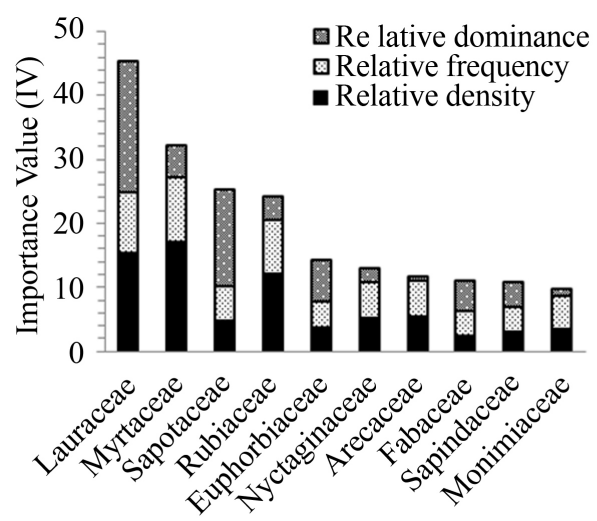

(a)

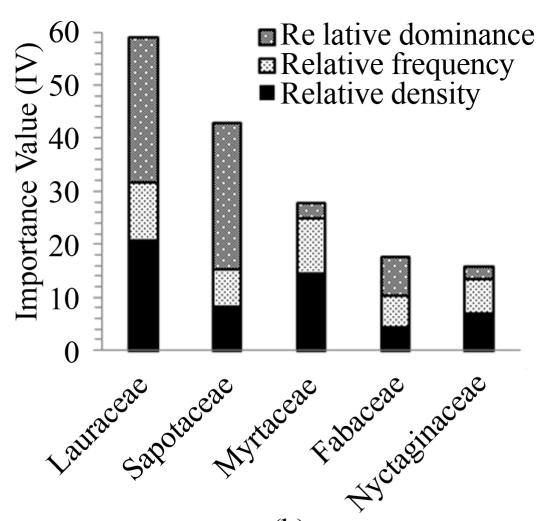

(b)

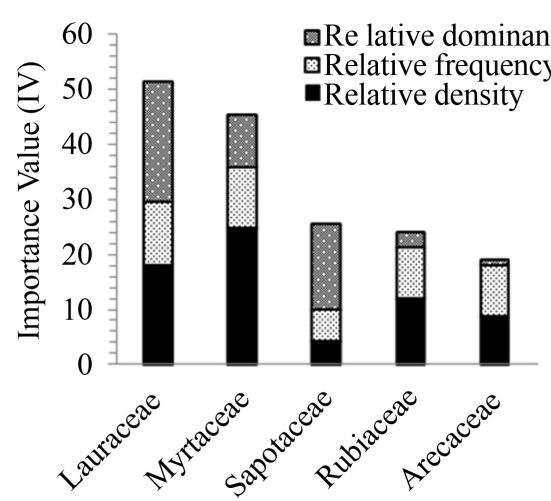

(c)

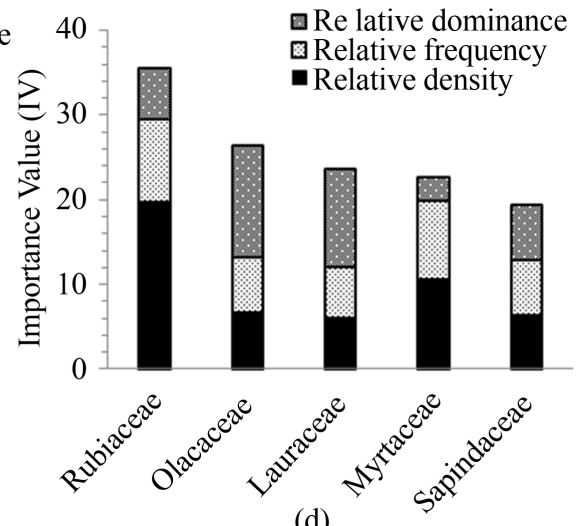

(d)

Figure 1. Structural parameters of the arboreal community from three mature Atlantic forests sampled in the São Paulo metropolitan region, Brazil. (a): Considering the three sites altogether; (b): Marsilac neighborhood, São Paulo municipality; (c): Morro Grande Forest Reserve, Cotia municipality; (d): Itapevi municipality.

(55.7\%), of which 98 were exclusive (27.8\%), while young forests (1.5 ha) had 254 species $(72.2 \%)$, of which 156 were exclusive (44.3\%).

The cluster dendrogram (cophenetic correlation $=0.86$ ) yielded two major groups: one composed only of mature forests and another composed of young or degraded secondary forests. In the DCA ordination diagram (Figure 2), secondary forests were concentrated on one end of axis 1 (eigenvalue $=0.63$ ) and mature forests were concentrated on the other.

Threatened and endemic species from forests of the São Paulo metropoli$\tan$ region

We recorded 31 species threatened with extinction ( $8.8 \%$ of 352 species) in the analyzed studies. Mature forests showed values ranging from 9 to 18 species (10.1\% to $18.9 \%)$, while young forests showed values ranging from 2 to 9 species (1.8\% to $11.7 \%$; Figure 3; supporting Information). Mature forests altogether (0.8 ha) showed $27(87.1 \%)$ threatened species, while young forests (1.5 ha) showed $14(45.2 \%)$ threatened species. Out of the 31 threatened species, 10 (32.3\%) occur in both young and mature forests, 4 (12.9\%) occur exclusively in the former and 17 (54.8\%) occur exclusively in the latter. 

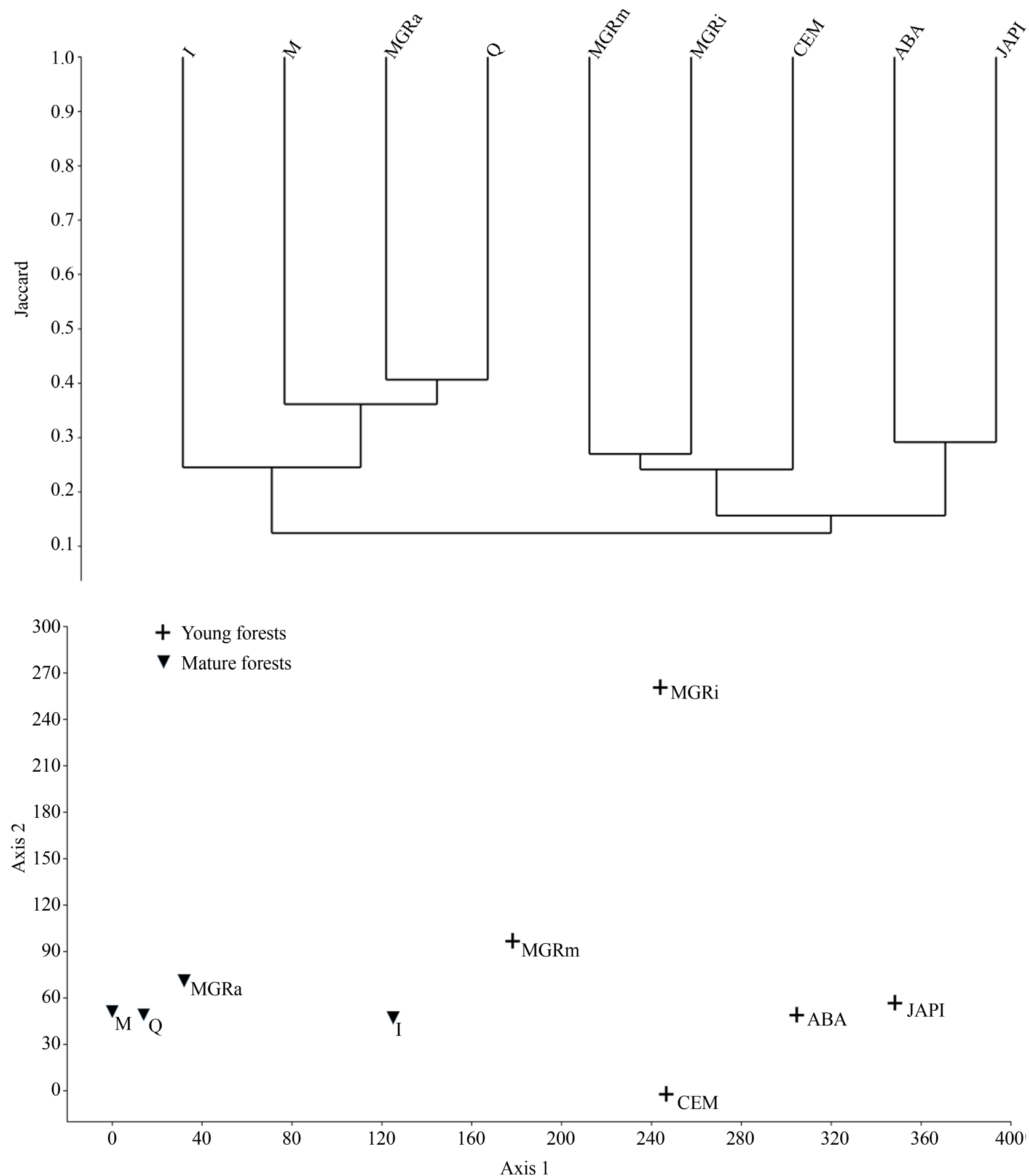

Figure 2. Cluster dendrograms (cophenetic correlation $=0.86$ ) and DCA (eigenvalues $=0.63$ and 0.31 for axes 1 and 2 , respectively) of Atlantic forests from the São Paulo metropolitan region, Brazil.

Regarding endemism, out of the 352 analyzed species, 118 (33.5\%) are endemic to the Brazilian Atlantic Forest. Of the 254 species recorded in 1.5 ha of young forests, $61(24.0 \%)$ are endemic to the Atlantic Forest, while in mature forests 90 (45.9\%) of the 196 species recorded in 0.8 ha are endemic. Of the 118 


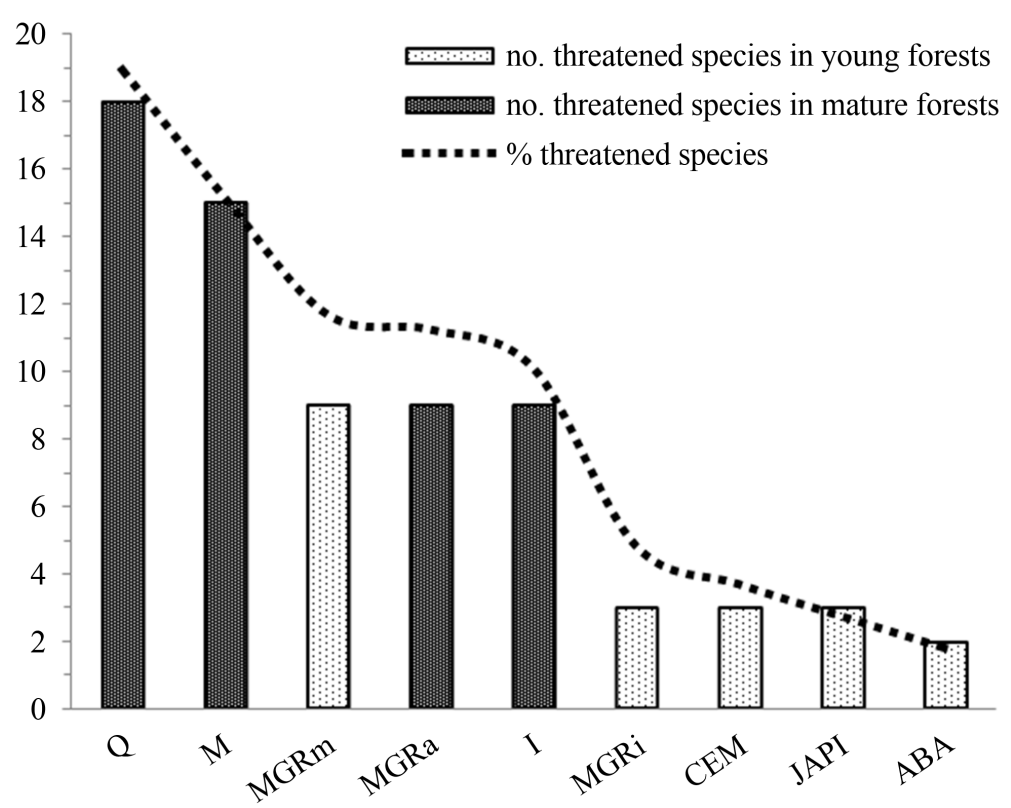

(a)

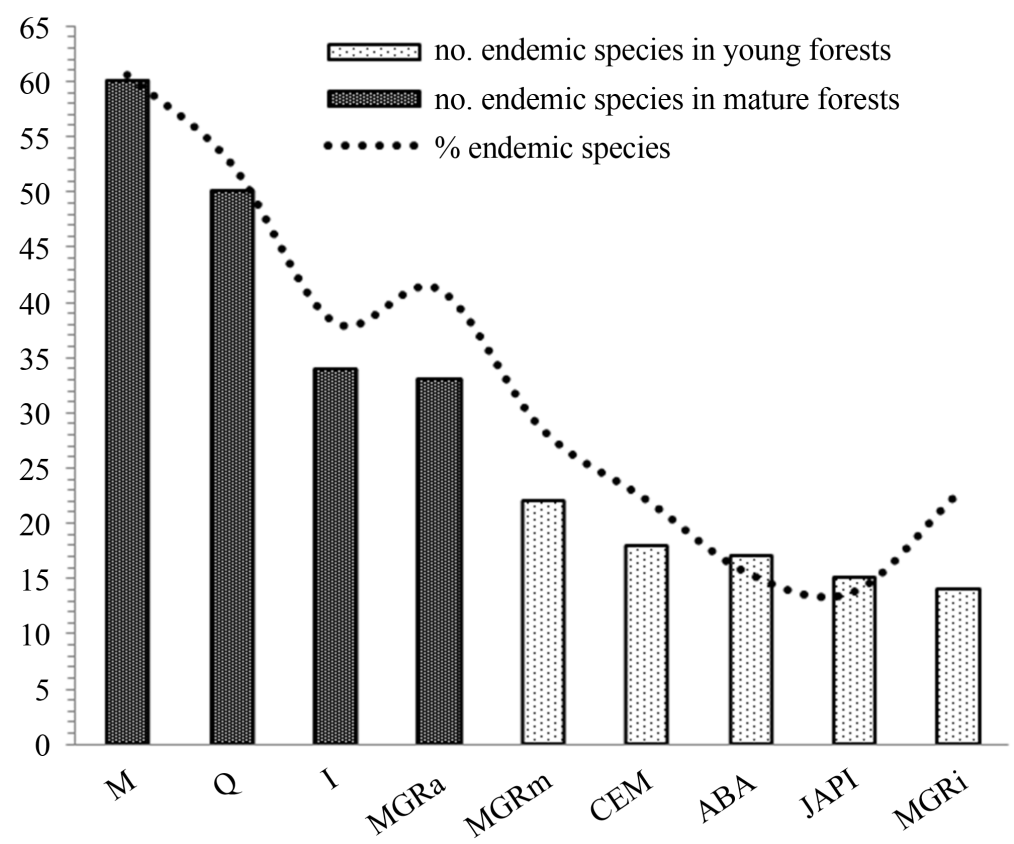

(b)

Figure 3. Comparative charts between young and mature Atlantic forests from the São Paulo metropolitan region, Brazil, regarding (a) the number and percentage of species threatened with extinction, according to [36] [37] [38] [39] and (b) the number and percentage of endemic species.

endemic species, $33(28.0 \%)$ occur in both mature and young forests, while 57 (48.3\%) and 28 (23.7\%) are exclusive to each one of them, respectively. Considering the studies separately, the number of endemic species to the Atlantic Forest ranged from 14 to 22 (13.8\% to $28.6 \%$ ) in young forests and from 34 to 60 (38.2\% to $60.6 \%$ ) in mature forests (Figure 3 ; supporting information). 


\section{Discussion}

The families that showed the highest IV in the total sampling (Myrtaceae, Lauraceae, Rubiaceae, and Sapotaceae) are frequently well represented in forests from the SPMR, except Sapotaceae. Myrtaceae and Lauraceae, which together account for $77.7 \%$ of the IV in the community, are important components of both secondary forests at the intermediary stage of regeneration and mature forests in the region, yet in the latter, these families show even higher values of richness and dominance. In very young forests, the presence of those two families is very low, and the predominant families are usually Asteraceae, Euphorbiaceae, Melastomataceae, Piperaceae, and Solanaceae [40]. Sapotaceae, a family typically associated with more well developed dense ombrophilous coastal forests, has higher representativeness in the SPMR exclusively in mature forests. In our sampling, this family showed high values of relative dominance due to the presence of large trees, yet it was represented by a few species (Micropholis crassipedicelata and Pouteria bullata).

The two species with the highest IV in the overall sampling (Micropholis crassipedicelata and Ocotea catharinensis) are among the main tree representatives that form the canopy of some mature forests in the region [11] [13] [32] and were very little sampled in young forests from the SPMR. As for the species that showed highest IV in the understory, Rudgea jasminoides and Guapira opposita are among the most abundant ones in some studies conducted in the region [13] [41], conversely to Calyptranthes lucida, a species which has been little sampled in young forests from the SPMR.

The formation of two major groups in the cluster dendrogram clearly showed the existence of a floristic cluster composed exclusively of young forests and another one formed by mature forests. This hypothesis is supported by the fact that forests from Morro Grande branched in different groups of the dendrogram, depending on the stage of regeneration or maturity of the community. Thus, mature forests from Morro Grande ( $\mathrm{Q}$ and MGRa) clustered together with the other mature forests (I and M), while the young forests, also from Morro Grande (MGRi and MGRm), clustered together with the other surveys conducted in young forest of the SPMR. The disposition of sites along axis 1 of the DCA corroborates the cluster results, with mature forests being located on one end of the axis and young ones being located on the other. The floristic difference between these two groups is evident in light of the fact that $72.2 \%$ of species were exclusive to either mature or young forests. Such floristic difference can be explained by the species substitution that occurs along with forest development, a variation which, as observed, can significantly influence the results of cluster and ordination analyses.

Data on species diversity, community structure, and the list of most important species (i.e., with highest IV) surveyed in our study, along with the compilation of data from other surveys conducted in the SPMR, provide substantial information for aiding the characterization of mature Atlantic Forests. Thus, all these 
data should be useful for the update of the Brazilian legislation on successional stages. Neither the main legal reference to Brazil nor the one to São Paulo state, i.e. the CONAMA Resolutions nos. 10 [42] and 01 [43], respectively, show any description of mature Atlantic Forests, nor do they bring any list of preferential species of that successional stage, which hampers its legal circumscription. The absence of an appropriate description in the CONAMA legislations may lead to serious distortions in processes of environmental licensing and inspection. Therefore, it is of paramount importance that the category 'mature forests' is legally created and properly characterized in a normative framework. Besides, the lists of preferential species of the successional stages described in CONAMA Resolution no. 01 [43] (i.e., early, intermediary, and late) lack revision. For instance, Ocotea spp. and Cryptocarya spp. are therein described as preferential species from the intermediary stage of regeneration, while we observed that these two genera are among some of the major representatives in mature forests of the region. Therefore, their reallocation between categories is needed to properly reflect the reality, as they are more well suited to more developed stages.

The Atlantic Forest is the most devastated biome in Brazil. It is also the biome with highest degree of endemism in the country: of the 15,001 angiosperm species recorded so far, $49.5 \%$ are endemic [1]. However, we verified that this percentage varies with forest maturity, as mature forests from the SPMR showed a higher percentage of endemic species (scores higher than 38.2\%) than young forests (scores lower than 28.6\%). Not only did mature forests show a higher percentage of endemic species, but also the number of such species in those forests was strikingly higher, 1.5 to 4.3 times higher than in young forests. Even in a total area almost twice as large, the analyzed young forests showed lower number of endemic species (61 species over $1.5 \mathrm{ha}$ ) than mature forests (90 species over $0.8 \mathrm{ha}$ ). The degree of endemism was relatively high in some mature forests, reaching values as high as $60.6 \%$ of species at Marsilac, which accounts for $50.8 \%$ of the overall endemism in only $8.7 \%$ of the total analyzed area $(2.3 \mathrm{ha})$. Besides, the number of endemic species that occurred exclusively in mature forests was 1.5 times higher than the one in young forests.

The presence of a large number of endemic species in mature forests had already been reported by [21] to tropical forests from Central America, albeit the author presented no quantitative data. Considering that the number of endemic species is reported as one of the main parameters to assess the importance of biodiversity in natural areas [3], mature forests may have major importance in the conservation of the arboreal flora from the SPMR. On the other hand, it should be noted that $24.1 \%$ of the endemic species occurred exclusively in young forests, a factor that should be taken into consideration for the elaboration of protective programs of the Atlantic Forest.

Besides the intrinsic importance of endemic species, the analysis of the number of threatened species is also fundamental to assess the importance of an environment for conservation. In that sense, we verified that mature forests have a 
high number of species threatened with extinction (notably $Q$ and $M$ ), with values overall being significantly higher than the ones verified in young forests. In fact, the number of threatened species in mature forests was as high as 9 times higher than in young forests. Furthermore, $80 \%$ of the analyzed young forests showed two to three threatened species (in areas of 0.2 to $0.4 \mathrm{ha}$ ), while mature forests showed more than 9 species (in areas of $0.2 \mathrm{ha}$ ). Not only the number of species was higher, but also the exclusivity of threatened species in mature forests $(54.8 \%)$ was 4.2 times higher than the one in young forests $(12.9 \%)$. While only one secondary forest at intermediary stage of regeneration (MGRm) showed a high number of threatened species (possibly due to its proximity to mature forests from Morro Grande Forest Reserve), the results suggest that more well preserved forests usually have a higher number of threatened species, a factor which undoubtedly increases their value for conservation in the SPMR.

The presence of a high number of threatened tree species in mature forests may be directly related to the scarcity of remnants with original forest or of well preserved environments. As the Brazilian Atlantic Forest is to a high extent composed of degraded forests, it is possible that the development of more rustic tree species, notably pioneer and early secondary ones, is being favored. This hypothesis is supported by the facts that none of the recorded threatened species is pioneer and only $9.7 \%$ of them are early secondary, the rest of them being late secondary (90.3\%). Analogously, most endemic tree species are late secondary (76.3\%), and this percentage is even higher for endemic species recorded exclusively in mature forests (87.7\%). Thus, it is probable that some of these species have difficulty in surviving the conditions of degradation that preponderate over most of the current Atlantic Forests, and they thus may remain restricted to a few patches of mature forest that provide more adequate conditions for their establishment and development.

While our analyses addressed a region-scale situation in the Atlantic Forest and assessed only the tree component (we do recommend their reapplication to other regions and with other components of the flora as well as other biotic groups), still the observed floristic differences and the high number of threatened and endemic species therein reinforce the idea that mature or primary forests possess a unique diversity and are irreplaceable for the maintenance of tropical biodiversity [12]. In view of these aspects and of the fact that only a small portion of the remaining $12.5 \%$ of Atlantic Forest vegetation is composed of mature Montane Ombrophilous Dense Forests, we consider such forests as priority areas for conservation, somewhat like hotspots within the Atlantic Forest hotspot, a similar approach to the one reported by [5] and [7] to the Mediterranean Basin hotspot. Those authors verified significant variation in the number of endemic species among sites within the same hotspot, including surveys conducted in different plant physiognomies and under varying environmental conditions. The authors [7] proposed the creation of the concepts of micro and nano hotspots, while [5] suggested the creation of the concepts of mega, 
macro and meso hotspots. In other words, the authors proposed the existence of hotspot hierarchies that depend on the size and degree of endemism found. The authors also reported that the degree of endemism is closely related to environmental conditions, especially altitude and precipitation. Unlike those authors, we compared flora surveys performed on only one type of plant physiognomy (Montane Ombrophilous Dense Forest), all such surveys being conducted in areas subjected to similar environmental conditions. Our results indicated that the degree of endemism (as well as the number of threatened species) may also vary significantly with other aspects, namely the maturity of the plant community.

The approach of considering the existence of small hotspots within larger hotspots highlights the need to consider Atlantic forests not only as a homogenous formation, yet as a mosaic of forests with different structures, floristic compositions, and number of endemic and threatened species, and thus each of those forests has different values for conservation. In that sense, studies aiming to map the remnants of mature forests are essential for the elaboration of conservation programs. Besides the need for preserving these remnants, it is equally important to create specific conservation programs that aim at the collection of propagules and production of vulnerable species, as well as their reintroduction in degraded forests. Similarly, the elaboration of projects that aim to connect these remnants to fragments of young forests and of other mature forests, aiming to enrich the former and reestablish gene flow among the latter, are also of great relevance.

The importance of conserving mature Atlantic forests had already been reported by [2], specifically to larger remnants, albeit the authors showed no data that reinforced their claim. Although the size of fragments was not an object of analysis in our study (the lack of data on their precise localization in other surveys precluded a comparative analysis), it is indisputable that large fragments may, in the long run, propitiate better conditions for species survival, which would thus render them pivotal for conservation, as discussed by [2]. On the other hand, in our study we verified the existence of small mature forest remnants in the SPMR, some of them isolated, that may still hold a significant diversity (especially of flora) and that may have great importance for conservation of the Atlantic Forest in the region, as they act as cores of high biodiversity and high endemism.

\section{Conclusion}

Most of the Atlantic Forest is composed of young or degraded vegetation, and thus fragments of mature or primary forests are rare. In fact, it is remarkable that patches of such forests still exist in the largest metropolitan region in South America. On the other hand, little is known on how many of them are there, where they can be found, their biological composition, and the structure and dynamics of the communities therein, which therefore results in a knowledge 
gap on the biota of one of the most biodiversity-rich and vulnerable forest formations on the planet. In view of the facts that they have a unique diversity, host significant populations of threatened and endemic species, and are scarce in terms of the number of remnants, we consider mature forests as hotspots within the Atlantic Forest hotspot in the São Paulo metropolitan region, such rare forests thus being categorized as of high relevance for conservation.

\section{Supporting Information}

The structural parameters of the studied arboreal communities as well the richness, IV of families and species (Appendix S1), sampling criteria, structural and diversity parameters of the phytosociological studies performed in the SPMR which were considered in the analysis (Appendix S2), and the list of species threatened with extinction and of endemic species to the Brazilian Atlantic Forest from young and mature forests (Appendix S3) are all available online. The authors are solely responsible for the content and functionality of these materials. Queries (other than the absence of material) should be directed to the corresponding author.

\section{Conflicts of Interest}

The authors declare no conflicts of interest regarding the publication of this paper.

\section{References}

[1] B.F.G. Brazilian Flora Group (2015) Growing Knowledge: An Overview of Seed Plant Diversity in Brazil. Rodriguésia, 66, 1085-1113. https://doi.org/10.1590/2175-7860201566411

[2] Ribeiro, M.C., Metzger, J.P.W., Martensen, A.C., Ponzoni, F.J. and Hirota, M.M. (2009) The Brazilian Atlantic Forest: How Much Is Left, and How Is the Remaining Forest Distributed? Implications for Conservation. Biological Conservation, 142, 1141-1153. https://doi.org/10.1590/2175-7860201566411

[3] Myers, N., Mittermeier, R.A., Mittermeier, C.G., da Fonseca, G.A.B. and Kent, J. (2000) Biodiversity Hotspots for Conservation Priorities. Nature, 403, 853-858. https://doi.org/10.1038/35002501

[4] Myers, N. (1988) Threatened Biotas: "Hot Spots" in Tropical Forests. The Environmentalist, 8, 187-208. https://doi.org/10.1007/BF02240252

[5] Cañadas, E.M., Fenu, G., Peñas, J., Lorite, J., Mattana, E. and Bacchetta, G. (2014) Hotspots within Hotspots: Endemic Plant Richness, Environmental Drivers, and Implications for Conservation. Biological Conservation, 170, 282-291. https://doi.org/10.1016/j.biocon.2013.12.007

[6] Murray-Smith, C., Brummitt, N.A., Oliveira-Filho, A.T., Bachman, S., Justin, M., Lughadha, E.M.N. and Lucas, E.J. (2009) Plant Diversity Hotspots in the Atlantic Coastal Forests of Brazil. Conservation Biology, 23, 151-163. https://doi.org/10.1111/j.1523-1739.2008.01075.x

[7] Fenu, G., Mattana, E., Congiu, A. and Bacchetta, G. (2010) The Endemic Vascular Flora of Supramontes (Sardinia), a Priority Plant Conservation Area. Candollea, 65, 347-358. https://doi.org/10.15553/c2010v652a10 
[8] Arroyo-Rodríguez, V., et al. (2017) Multiple Successional Pathways in Human Modified Tropical Landscapes: New Insights from Forest Succession, Forest Fragmentation and Landscape Ecology Research. Biological Reviews, 92, 326-340. https://doi.org/10.1111/brv.12231

[9] S.O.S. Mata Atlântica and INPE (coords.) (2015) Atlas dos remanescentes florestais da Mata Atlântica período 2013-2014. Fundação SOS Mata Atlântica e Instituto Nacional de Pesquisas Espaciais, São Paulo.

[10] Barlow, J., et al. (2007) Quantifying the Biodiversity Value of Tropical Primary, Secondary, and Plantation Forests. Proceedings of the National Academy of Sciences of the United States of America, 104, 18555-18560.

https://doi.org/10.1073/pnas.0703333104

[11] Barretto, E.H.P. and Catharino, E.L.M. (2015) Florestas maduras da região metropolitana de São Paulo: Diversidade, composição arbórea e variação florística ao longo de um gradiente litoral-interior, Estado de São Paulo, Brasil. Hoehnea, 42, 445-469. https://doi.org/10.1590/2236-8906-72/2014

[12] Gibson, L., et al. (2011) Primary Forests Are Irreplaceable for Sustaining Tropical Biodiversity. Nature, 478, 378-381. https://doi.org/10.1038/nature10425

[13] Catharino, E.L.M., Bernacci, L.C., Franco, G.A.D.C., Durigan, G. and Metzger, J.P.W. (2006) Aspectos da composição e diversidade do componente arbóreo das florestas da Reserva Florestal do Morro Grande, Cotia, SP. Biota Neotropica, 6, 1-28. https://doi.org/10.1590/S1676-06032006000200004

[14] Rodrigues, E.A., et al. (2020) Serviços Ecossistêmicos e Bem-Estar Humano na Reserva da Biosfera do Cinturão verde da Cidade de São Paulo. Secretaria de Infraestrutura e Meio Ambiente, Instituto Florestal, São Paulo, 608 p.

[15] Catharino, E.L.M. and Aragaki, S.A. (2008) A vegetação do município de São Paulo: De Piratininga à metrópole paulistana. In: Malagoli, L.R., Bajesteiro, F.B. and Whately, M., Eds., Além do concreto: Contribuições para a proteção da biodiversidade paulistana, Instituto Socioambiental, São Paulo, 54-89.

[16] Metzger, J.P.W., Alves, L.F., Goulart, W., Teixeira, A.M.G., Simões, S.J.C. and Catharino, E.L.M. (2006) Uma área de relevante interesse biológico, porém pouco conhecida: A Reserva Florestal do Morro Grande. Biota Neotropica, 6, 1-33. https://doi.org/10.1590/S1676-06032006000200003

[17] Metzger, J.P.W., Alves, L.F., Pardini, R., Dixo, M., Nogueira, A.A., Negrão, M.F.F., Martensen, A.C. and Catharino, E.L.M. (2006) Características ecológicas e implicações para a conservação da Reserva Florestal do Morro Grande. Biota Neotropica, 6, 1-13. https://doi.org/10.1590/S1676-06032006000200011

[18] Arzolla, F.A.R.D.P. (2002) Florística e fitossociologia de trecho da Serra da Cantareira, Núcleo Águas Claras, Parque Estadual da Cantareira, Mairiporã-SP. Dissertação de Mestrado, Universidade Estadual de Campinas, Campinas.

[19] Arzolla, F.A.R.D.P. (2012) Meio Biótico. In: Plano de Manejo do Parque Estadual Alberto Löfgren, Secretaria do Meio Ambiente. Instituto Florestal, São Paulo, 111-143.

[20] Budowski, G. (1963) Forest Succession in Tropical Lowlands. Turrialba, 13, 42-44.

[21] Budowski, G. (1965) Distribution of Tropical American Rainforest Species in the Light of Successional Processes. Turrialba, 15, 41-42.

[22] Budowski, G. (1970) The Distinction between Old Secondary and Climax Species in Tropical Central American Lowlands Forests. Tropical Ecology, 11, 44-48.

[23] Hartshorn, G.S. (1980) Neotropical Forest Dynamics. Biotropica, 12, 23-30. https://doi.org/10.2307/2388152 
[24] Guarigata, M.R. and Ostertag, R. (2001) Neotropical Secondary Forest Succession: Changes in Structural and Functional Characteristics. Forest Ecology and Management, 148, 185-206. https://doi.org/10.1016/S0378-1127(00)00535-1

[25] Setzer, J. (1966) Atlas climático e ecológico do Estado de São Paulo. Comissão Interestadual da bacia do Paraná e Centrais Elétricas de São Paulo, São Paulo, SP.

[26] I.B.G.E. Instituto Brasileiro de Geografia e Estatística (2012) Manual técnico da Vegetação Brasileira. Rio de Janeiro, $171 \mathrm{p}$.

[27] A.P.G. III (2009) An Update of the Angiosperm Phylogeny Group Classification for the Orders and Families of Flowering Plants: APG III. Botanical Journal of the Linnean Society, 161, 105-121. https://doi.org/10.1111/j.1095-8339.2009.00996.x

[28] Forzza, R.C., Stehmann, J.R. and Nadruz, M. (2016) List of Species of the Brazilian Flora. http://floradobrasil.jbrj.gov.br

[29] Hill, M.O. and Gauch, H.G. (1980) Detrended Correspondence Analysis: An Improved Ordination Technique. Vegetation, 42, 47-58. https://doi.org/10.1007/BF00048870

[30] Hammer, O., Harper, D.A.T. and Ryan, P.D. (2001) PAST 2.17c. Paleontological Statistics Software Package for Education and Data Analysis. Palaeontologia Electronica, 4, 1-9.

[31] Wanderley, M.G.L., et al. (2011) Checklist das Spermatophyta do Estado de São Paulo, Brasil. Biota Neotropica, 11, 193-390. https://doi.org/10.1590/S1676-06032011000500013

[32] Rosário, R.P.G. (2010) Estágios sucessionais e o enquadramento jurídico das florestas montanas secundárias na Reserva Florestal do Morro Grande (Cotia, SP) e entorno. Dissertação de Mestrado, Instituto de Botânica da Secretaria de Estado do Meio Ambiente, São Paulo.

[33] Ogata, H. and Gomes, E.P.C. (2006) Estrutura e composição da vegetação no Parque CEMUCAM, Cotia, SP. Hoehnea, 33, 371-384.

[34] Grombone, M.T., Bernacci, L.C., Meira-Neto, J.A.A., Tamashiro, J.Y. and LeitãoFilho, H.F. (1990) Estrutura fitossociológica de uma floresta semidecídua de altitude do Parque Estadual de Grota Funda (Atibaia, SP). Acta Botanica Brasilica, 4, 47-64. https://doi.org/10.1590/S0102-33061990000200004

[35] Rodrigues, R.R. (1986) Levantamento florístico e fitossociológico das matas da Serra do Japi, Jundiaí, SP. Dissertação de mestrado, Universidade Estadual de Campinas, Campinas.

[36] I.U.C.N. (World Conservation Union) (2013) IUCN Red List of Threatened Species. Version 201. http://www.redlist.org

[37] M.M.A. (Ministério do Meio Ambiente) (2008) Instrução Normativa n. 06, 23 September 2008. Lista Oficial de Espécies da Flora Brasileira Ameaçada de Extinção. Diário Oficial da União, 185, 75-83.

[38] Martinelli, G. and Moraes, M.A. (orgs.) (2013) Livro Vermelho da Flora do Brasil. Instituto de Pesquisas Jardim Botânico do Rio de Janeiro, Rio de Janeiro, 1100 p.

[39] S.M.A. 48 (2004) Secretaria do Meio Ambiente do Estado de São Paulo. Resolução SMA n. 48, 21 September 2004. Lista oficial das espécies da flora do Estado de São Paulo ameaçadas de extinção. Diário Oficial do Estado de São Paulo, 114, 26-29.

[40] Arzolla, F.A.R.D.P. (2011) Florestas secundárias e a regeneração natural de clareiras antrópicas na Serra da Cantareira, SP. Tese de Doutorado, Universidade Estadual de Campinas, Campinas. 
[41] Leite, E.C. (1995) Ecologia de um fragmento florestal em São Roque, SP: Florística, fitossociologia e silvigênese. Dissertação de Mestrado, Universidade Estadual de Campinas, Campinas.

[42] Conselho Nacional do Meio Ambiente (1993) Resolução CONAMA n. 10, de 1 de outubro de 1993. Estabelece os parâmetros básicos para análise dos estágios de sucessão da Mata Atlântica. Diário Oficial da União, 209, 16497-16498.

[43] Conselho Nacional do Meio Ambiente (1994) Resolução CONAMA n. 01, de 31 de janeiro de 1994. Regulamenta o Decreto n. 750, de 10 de fevereiro de 1993 e a Resolução CONAMA ${ }^{\circ} 10$ de $1^{\circ}$ de outubro de 1993 em relação à necessidade de se definir vegetação primária e secundária nos estágios pioneiro, inicial, médio e avançado de regeneração de Mata Atlântica a fim de orientar os procedimentos de licenciamento de exploração nativa do Estado de São Paulo. Diário Oficial da União, 24, 1684-1685. 